\title{
Agricultural impacts of longwall mine subsidence: the experience in Illinois, USA and Queensland, Australia
}

\author{
Robert G. Darmody $\cdot$ R. Bauer $\cdot$ D. Barkley $\cdot$ S. Clarke $\cdot$ D. Hamilton
}

Received: 1 July 2014/Revised: 20 July 2014/ Accepted: 25 July 2014/Published online: 9 October 2014

(C) The Author(s) 2014. This article is published with open access at Springerlink.com

\begin{abstract}
Unlike conventional room and pillar underground coal mining, where subsidence is designed to be prevented, subsidence is a planned outcome of other methodologies. These include high extraction retreat, where the roof supporting pillars are systematically removed, and longwall mining, which employs a machine that mines a continuous strip of coal, thus leaving no roof supports. Both types result in the surface dropping $\sim 70 \%$ of the mined-out thickness. In Illinois there was a concern that farm land thus subsided would be lost to productive agriculture. Consequently, the possibility that planned mine subsidence would be banned in Illinois lead to the creation of the Illinois Mine Subsidence Research Program in 1985 to investigate agricultural impacts of planned mine subsidence and the possibility of mitigating its impact. Its findings established that subsidence was not as detrimental as feared and that the impacts could be mitigated. The project was a successful collaboration of state and federal governments and local Universities. Similarly, in Queensland, longwall mining is opposed by some in the farming community. In response, Bandanna Energy, the company planning the mining, organized the Agricultural Coexistence Research Committee to oversee research into the mitigation of longwall mining impacts. Although the soils, climate, and regulatory regimes are different, concerns of the local communities are similar.
\end{abstract}

Keywords Agricultural impact $\cdot$ Longwall mine subsidence $\cdot$ Coal mining subsidence $\cdot$ Subsidence mitigation

\section{Citizen concerns about longwall mining}

There are advantages of longwall mining over conventional room and pillar mining. These include a higher extraction ratio, leaving less coal in the ground unavailable for use; a safer mining process due to fewer underground personnel and a known roof failure plan; and generally lower production costs. Additionally, the subsidence associated with longwall mining is immediate and predictable; at typically about $70 \%$ of the mined seem thickness, unlike

R. G. Darmody $(\bowtie) \cdot$ R. Bauer · D. Barkley

Land Reclamation Division, Illinois Natural Resources

Department, Illinois Prairie Research Institute, University of

Illinois, Champaign, USA

e-mail: rdarmody@illinois.edu

S. Clarke $\cdot$ D. Hamilton

Bandanna Energy Limited and Agricultural Coexistence

Research Committee, Brisbane, Australia conventional mining where subsidence might occur sometime in the future without an identifiable entity to repair the damage. However, any subsidence might be considered unacceptable to residents where longwall mining is planned. Concerns included; damage to structures and buildings; surface cracks; erosion and slope instability; disruption of surface and groundwater with the possibility of salinization; increased soil wetness and ponding; access to fields, disrupted farming patterns; and depressed crop yields.

Illinois has large reserves of bituminous coal, which underlie some of the best farmland in the world, technically and legally identified as "Prime Farmland." In the early 1980s coal companies planned to take advantage of those reserves and of the efficiency of longwall mining, and a related form of mining known as High Extraction Retreat where the roof supporting coal pillars are removed to increase production ratios. However, longwall mining was new to the region. When it was introduced into Illinois 
there were concerns that crop yields would be greatly diminished and the value of the land would be reduced in perpetuity. Consequently, there was a push by agricultural organizations to have longwall mining banned outright.

Queensland Australia also has large reserves of coal. Now there are proposed longwall mines beneath lands containing their best farmland, known as "Strategic Cropping Land." The story in Queensland is similar, but not the same, as in Illinois due to differences in crops, climate, landscapes, and soils. However, longwall mining works well in both locations and the concerns are for the protection of agriculture over the long term, and not the short term benefits of longwall mining for coal would bring.

To respond to citizens' concerns about longwall mining in Illinois back in the 1980s, the Illinois Mine Subsidence Research Program was established, and recently in Queensland, the Agricultural Coexistence Research Committee was created. As with the environmental differences between the two locals, the origins of the research committees differ, but their objectives are similar.

\section{Beginnings of the Illinois mine subsidence research program (IMSRP)}

Paul DuMontelle, the original director of the Illinois mine subsidence research program (IMSRP), described the program as "a three-way collaboration between Illinois' two major industries, agriculture and coal, and scientists from all over the state. We're specifically concerned with active mines using high-extraction and room-and-pillar techniques. What we want to find out is how subsidence-the settling or sagging of acreage over underground minesaffects farmland. We also need to develop guidelines for mitigation or repair". In the early 1980s, the Illinois Farm Bureau (IFB) and the Illinois Coal Association (ICA) began meeting to discuss their mutual concerns. The IFB stated that, "Originally, we were more worried about the effects of strip mining, but subsidence gradually emerged as a serious problem. Farmers kept raising questions that no one had the answers to. The basic scientific research just wasn't there." Some of these questions were whether subsidence would have long-term effects on farmland, how different coal mining methods might affect the land, and what could be done to predict subsidence and plan for it in advance. The ICA realized the need for subsidence research in Illinois and started looking for the right people to conduct it and the money to fund it.

The Illinois State Legislators felt that subsidence research was important for the state and backed the proposed program. The U.S. Bureau of Mines (USBM) sup- plied federal funding. State funding was provided by the Illinois Coal Development Board of the Illinois Department of Energy and Natural Resources. The Illinois State Geological Survey and the Twin Cities Research Center of the USBM was charged to conduct the research. The IMSRP was organized in 1985 under the direction of the Illinois State Geological Survey in cooperation with U.S. Bureau of Mines. It was one of the first comprehensive subsidence research programs in the United States and the only program to investigate subsidence impacts on crop yields. The IMSRP was committed to increasing the productivity of both industries (ISGS 1988). These activities reflected an on-going and growing environmental awareness in the US which was eventually codified in legislation, in particular the federal law known as SMCRA.

\section{Brief history of the surface control and reclamation act (SMCRA)}

In the United States, the right to private property is paramount. However, over the years the concerns about the permanent, destructive impact of mining grew, and along with it, a realization of the need for regulation. In other words, mining companies had some obligation to the larger society and to posterity. Consequently, the US congress began hearings on surface coal mining regulation in 1968. On August 3, 1977, President Carter signed SMCRA into law. The Act established the Office of Surface Mining Reclamation and Enforcement (OSMRE) within the Department of the Interior to carry out the provisions of the law. SMCRA was the first federal environmental statute to regulate a specific industry as opposed to a specific type of pollution. It created two major programs: (1) An abandoned mine land reclamation program, funded by fees that current operators pay, to reclaim places adversely affected by abandoned coal mines; (2) A regulatory program to ensure that surface coal mining operations are conducted and reclaimed in an environmentally sound manner. The subsequent Energy Policy Act required that underground mine operators correct subsidence damage to residential structures. Later OSMRE announced an oversight improvement initiative to expand public involvement, increase oversight inspections, and clarified OSMRE's role in overseeing state permitting actions (OSMRE 2014). Under the terms of SMCRA state primacy rules, Illinois' Office of Mines and Minerals became the lead mining regulatory authority in 1983. It is the responsibility of the Illinois Department of Natural Resources to issue mine permits that must include subsidence mitigation plans. It later acts as "middle man" in arbitrating enforcement issues between the landowners and the mine company. 


\section{Agriculture and longwall mining in Illinois}

The area of overlap of longwall mining and agriculture is predominately in southern Illinois. Locally, the climate is humid, and the soils are commonly poorly drained. Corn (maize) and soy bean are the common crops. Given the low relief, the major impact of subsidence is in the creation of ponded areas within the mined out panels. To remedy this situation, the mining companies have several approaches; cut drainage ditches; add fill; re-contouring; additional tile lines with surface inlets; or any combination of the above methods. However, there was no reassurance that these methods would result in restoration of crop yields, thus the need for an independent research program.

\section{Subsidence and agriculture research in Queensland}

The vast majority of the research done on agricultural impacts of longwall mining was done as part of the IMSRP in Illinois in the 1980s and 90s. There have been advances in technology since then that should make modern, contemporary research more easily accomplished. The Springsure Creek Agricultural Coexistence Research Committee (ACRC) has been established by Bandanna Energy to guide the Coexistence Research Program for the Springsure Creek Coal Project. Bandanna Energy has allocated $\sim \$ 3.5 \mathrm{M}$ AUD to support ACRC. Research project areas are proposed and "Expression of Interests" solicited from independent researchers. In contrast to IMSRP, social science projects are included in the ACRC goals. Environmental and agricultural conditions are different in Illinois and Queensland, but the agricultural community's concerns are essentially the same, the question remains essentially "what will the area be like after longwall mining?"

\section{Local conditions at the proposed Springsure Creek, Queensland longwall mine}

Springsure Creek is situated on Queensland's Central Highlands, a productive agricultural region for growing field crops and producing livestock, sheep, and beef cattle. The region produces grain sorghum, wheat, and chickpeas and where irrigation water is available, cotton. Most of the agriculture in the region relies on rainfall, but Fairbairn Dam, the west of Springsure Creek, impounds some 1.44 million megaliters of water which is principally used for irrigation. In addition, some farmers have built on-farm water storages which utilize local runoff stored for irrigation.

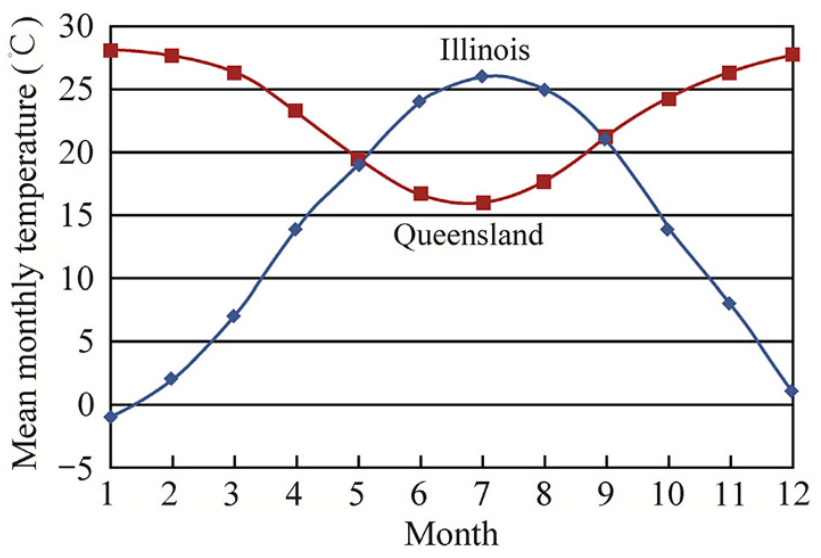

Fig. 1 Mean monthly temperature in Southern Illinois (diamond) and in Queensland (rectangle)

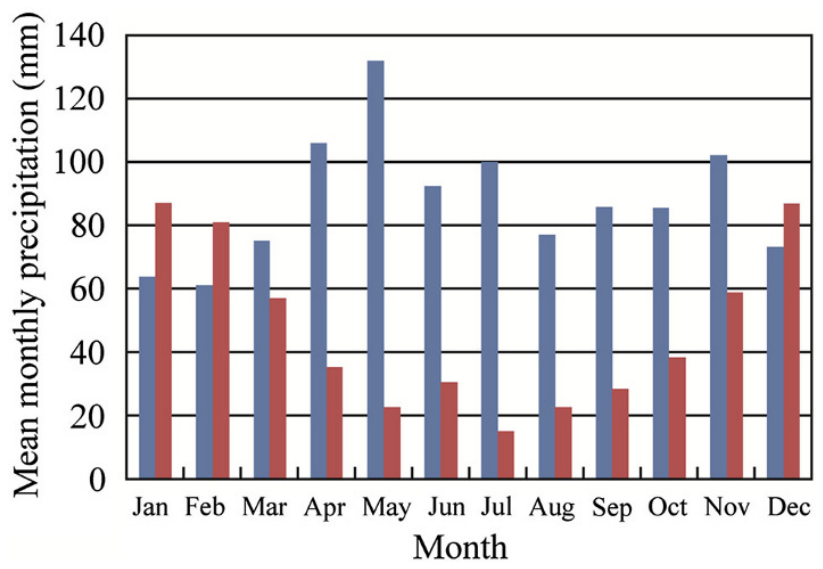

Fig. 2 Mean monthly precipitation in Southern Illinois (left bar) and in Queensland (right bar)

The climate in the central highlands is sub-humid to semi-arid subtropical, and rainfall is highly variable, strongly summer-dominant with common summer high intensity rainfall events. Air temperatures are warm to hot in summer and mild in winter. Heat waves are common from October to March and frosts occur occasionally in most seasons from May to August. Specifically, the region experiences an average annual rainfall of around $640 \mathrm{~mm}$ with over $70 \%$ falling in the months of October to March. The occasional intense events cause severe soil erosion on the long, cultivated slopes of highly erodible soils. Rainfall events are usually from storms, but ex-tropical cyclones, travelling inland as rainfall depressions, can result in high rainfall totals as well. Evaporation rates can be high, with evaporation rates exceeding $10 \mathrm{~mm}$ per day during the summer months. Due to the high temperatures and variable rainfall patterns, drought is a common feature of the climate (Figs. 1, 2). 
The landscape of the region is undulating, with soils formed on basalt residuum, Tertiary sediments, or on the alluvial plains associated with rivers and streams. The soils formed on the recent alluvial plains are cracking clay soils (Vertisols) or what are locally known as duplex soils (Ultisols possibly in the US soil taxonomic system). On the older alluvium and basalt, cracking clay soils predominate. The soils formed on tertiary sediments are red earths on the crests (Oxisols?) and duplex and gradational soils (Inceptisols) on the lower slopes (Tucker et al. 2003).

The natural vegetation in the region consists of brigalow (Acacia harpophylla), little-leafed bauhinia (Lysiphyllum carronii), and coolabah (Eucalyptus coolabah). On the shallow cracking soils formed on basalt, open woodland or grasslands occur and on the duplex soils, poplar box (Eucalyptus populnea) predominates. On the lower slopes, the deeper, more fertile soils carry yellowwood (Terminalia oblongata) in association with brigalow. However, the native vegetation has largely been cleared on the better soils to enable cultivation. These cracking clay soils (and some of the red earths) are naturally fertile, and have a Plant Available Water Capacity (PAWC) of between 100 and $180 \mathrm{~mm}$. The soils on the lower slopes are inherently fertile as well, particularly where the original native vegetation consisted of brigalow and yellowwood. In some cases, the soils are quite saline at depth (below $600 \mathrm{~mm}$ ) and the duplex soils usually have sodic subsoils. From an agricultural perspective, once they are cultivated these soils experience a decline in soil fertility. They are naturally very fertile (high levels of nitrogen) under brigalow (a legume species) but require phosphorus fertilizer. After a period of cultivation, particularly with irrigation, nitrogenous fertilizers are also required (Dalal and Mayer 1986).

Grain sorghum is the principal summer crop and it usually is planted in January to take advantage of stored soil water and summer rainfall. Yields are moderate, usually less than 5 tonnes per hectare with the average yield for the region being 1.6-1.8 tonnes per hectare. Most farms grow areas in excess of 1000 ha to compensate for the low yield. Because the crop relies on stored soil water and because rainfall is less frequent in late summer. Most crops experience a "terminal drought." Wheat is the main winter crop, planted in April and May, although some crops are planted earlier to enable them to avoid frost at flowering time. Yields seldom exceed 5 tonnes per hectare in raingrown conditions. Chickpeas have become a favored winter crop in recent years because of their drought hardiness and ability to exploit stored soil water. Yields of 2.5 tonnes per hectare are common. Under irrigated conditions, cotton is the preferred crop although maize is also grown. Irrigated cotton yields can exceed 10 bales per hectare and irrigated maize yields can also exceed 10 tonnes per hectare.
While agriculture dominates the region, coal mining has had a central place in the central Queensland economy for decades. The Bowen Basin supports over forty mines, mostly open cut. Historically, open cut mines have been the preferred mining method, but longwall mining is gaining favor because new technologies make this mining method attractive economically, and because the impact on the landscape is less severe than open cut mining. Bandanna Energy has a mining exploration lease in the Springsure Creek region which encompasses some of the best cropping soils of the central Queensland region. These soils, classified as Strategic Cropping Soils, are recognized as important by the government and to be preserved. Bandanna Energy has allocated funds of in excess of $\$ 3.5 \mathrm{M}$ AUD to establish the Agricultural Coexistence Research Committee (ACRC) to oversee a research program aimed at maintaining natural resources and agricultural productivity during mining operations. A goal of ACRC is to enable restoration of agricultural productivity on areas affected by mining activities including subsided areas. In addition, research to understand community expectations and identify strategies to minimize adverse impacts and maximize the social and economic benefits of the mining investment to local and communities are additional goals of the program.

\section{Mining regulatory situations in Illinois and Queensland}

In Queensland, mineral rights are owned by the State Government and mining companies need to get approval from the Commonwealth plus the State Government to proceed with a mine plan. The Commonwealth is concerned with matters of National Environmental Significance (e.g. rare or endangered species, and water quantity and quality), while the State is concerned with mineral rights, local environment, and social impacts. At the State level, there is new and changing legislation relevant to the political party and public perceptions/populist politics in government (which has a 3 year election cycle). There are multiagency, different statutory timeframe requirements, some legislation has timeframe limitations, and others do not. The coordination between government departments and between different legislation concerns is largely company-driven. Some of the steps and hurdles involved in mining lease approval in Queensland include (1) Environmental approval (including public consultation), (2) Strategic Cropping Land approval, (3) Landholder approval for access and surface disturbance (negotiated agreements), (4) Cultural Heritage approval (negotiated agreements), (5) Native Title approval (negotiated agreements), (6) Overlapping tenure holder approval (negotiated 
agreements), and (7) Local Government approval for access and services (negotiated agreements). In short, "the Queensland Government is committed to protecting the State's best cropping land, called strategic cropping land, from development that will have an adverse impact on the productive capacity of the land"(Queensland Government 2014).

In Illinois, subsidence control plans must include a map of existing and projected subsidence contours. The projected contours must define potential drainage problems and the plans must show how drainage interruptions will be corrected, which may include plans for addition of drainage tile to supplement surface drainage. Moreover, temporary crop damage compensation is required until repair is complete.

In Illinois, in order to have the legal rights to longwall mine, a company must have the right to mine coal, as well as the right to subside the surface, which is typically part of the coal severance deed. This right is obtained as a separate agreement with surface owner. All approvals must be in place and rights established prior to subsidence. Post mining, there are performance standards for subsidence impacts including; (1) All land must be restored to its premining capability; (2) All structures must be repaired, replaced, or compensated for, (3) All drinking and domestic water supplies (wells and springs) must be restored or replaced.

\section{Findings of IMSRP}

The IMSRP involved a four year research project in keeping with its specific objectives to determine the; (1) impact of mine subsidence on agricultural soils; (2) overall impact of coal mine subsidence on crop yields; and (3) effectiveness of subsidence mitigation on crop yields, The first step was to determine the aerial extent of subsidence impacted areas (Darmody et al. 1988). We used infrared aerial photographs taken in early spring to show increased wetness. We defined three levels of impact, none to slight was most common at $94 \%$, followed by moderate at $4 \%$, and severe at $2 \%$ of the mine panel area (Table 1).

Table 1 Aerial extent of subsidence induced damage to agricultural fields in Illinois

\begin{tabular}{llc}
\hline Estimated impact & \multicolumn{2}{l}{ Longwall panel area impacted $^{\mathrm{a}}$} \\
\cline { 2 - 3 } & Area (Ha) & Area (\%) \\
\hline None-slight & 56 & 94 \\
Moderate & 2.4 & 4 \\
Severe & 1.2 & 2 \\
\hline
\end{tabular}

$\overline{{ }^{a} \text { Based on interpretation of spring time infrared aerial photographs }}$ and mining maps, unmitigated
Table 2 Crop yield reductions on unmitigated subsided agricultural fields in Illinois

\begin{tabular}{lllll}
\hline Subsidence impact & \multicolumn{4}{l}{ Corn yield reduction $(\%)^{\text {a }}$} \\
\cline { 2 - 5 } & Year 1 & Year 2 & Year 3 & Mean \\
\hline Slight & \multicolumn{4}{l}{ Not significant } \\
Moderate & 52 & 56 & 22 & 43 \\
Severe & 95 & 99 & 91 & 95 \\
\hline
\end{tabular}

${ }^{a}$ Average reduction in yield, without regard to mitigation efforts

Table 3 Overall crop yield reductions on subsided agricultural fields in Illinois

\begin{tabular}{lllll}
\hline Mining type & \multicolumn{4}{l}{ Corn yield reduction $(\%)^{\mathrm{a}}$} \\
\cline { 2 - 5 } & Year 1 & Year 2 & Year 3 & Mean \\
\hline Longwall & 7.4 & 4.2 & 2.4 & 4.7 \\
High extraction retreat & 2.4 & 2.2 & 0.9 & 1.8 \\
\hline
\end{tabular}

${ }^{a}$ Weighted average reduction in yield. Includes the yield reduction weighted by the impact class area

Table 4 Impact of slope on subsidence severity in Illinois

\begin{tabular}{|c|c|c|c|c|}
\hline \multicolumn{5}{|c|}{ Slope range $(\%)$} \\
\hline $0-1.5$ & $1.5-4$ & $4-7$ & $7-12$ & $>12$ \\
\hline \multicolumn{5}{|c|}{ Moderate + severe subsidence impacts frequency $(\%)$} \\
\hline 53.6 & 27.6 & 13.0 & 5.8 & 0 \\
\hline
\end{tabular}

Next, we determined yields in these three impact areas in comparison to similar, but un-mined, reference areas (Darmody et al. 1989). Those yield reductions averaged over the research period, were; non-significant, 43 and $95 \%$ of the reference areas for the slight, moderate, and severe impacted areas, respectively (Table 2).

The combination of the two approaches resulted in an estimated overall weighted average yield reduction for longwall and high extraction retreat mining of 4.7 and $1.8 \%$, respectively, for all sites over the research period (Table 3).

Additional findings included noting that soil chemistry or physical properties did not control yield variability, and that weather had a profound impact on subsided soils. Wet sites pond more rain water in wetter years, which is an advantage in a drought, but a major disadvantage in a wet year. This situation is reflected in the relationship between soil slope and subsidence impact, where more sloping ground is more susceptible to subsidence in Illinois' rainy climate (Table 4).

As a final aspect of the research project, we evaluated the success of mitigation in restoring crop yields. It turned out that soybean yields were not statistically different from reference areas, but corn yields were lower, $81 \%$ of reference areas, in mitigated areas (Table 5). 
Table 5 Crop yields on mitigated subsidence agricultural fields in Illinois

\begin{tabular}{llllll}
\hline Crop & \multicolumn{4}{l}{ Yield difference on mitigated subsidence fields (\% of ref.) } \\
\cline { 2 - 6 } & Year 1 & Year 2 & Year 3 & Year 4 & Mean \\
\hline Corn & 101 & 93 & $71^{*}$ & $70^{*}$ & $81^{*}$ \\
Soybean & 96 & $124 *$ & $86^{*}$ & $81^{*}$ & 93 \\
\hline
\end{tabular}

* Significant at $5 \%$. Results are a snap shot of then current conditions and do not necessarily reflect attempts to mitigate problems repeatedly

The takeaway message of the IMSRP was that success of subsidence mitigation depends on local conditions and efforts applied to correct related problems. A recent independent follow-up research project corroborated the findings of the IMSRP (OSMRE 2011). It indicated that the total area of prime farmland soils within the evaluation area not being used for crop production or that should not be used for crop production due to longwall mining subsidence mitigation activities was 4.44 acres or one-quarter of one percent of the prime farmland soils within the evaluation area.

\section{Conclusions}

Conditions in Australia are challenging for subsidence research given the long slopes, potential for salt problems, and in particular the highly variable and marginal climate. However in comparison to IMSRP, the ACRC has some advantages. Modern GPS enabled yield monitors will make crop yield estimates more accurate. Given that mining has not commenced yet, research will have a lead time that the IMSRP did not have. As mentioned before, a complexity is that the high climatic variability in Queensland will make it necessary to have a long record before effects can be evaluated statistically. Erosion, not drainage will be more important in Queensland than in Illinois. Changes in QL groundwater may lead to saline seeps. And no matter what the research shows, citizen opposition may continue, despite research results, aesthetics count.

Open Access This article is distributed under the terms of the Creative Commons Attribution License which permits any use, distribution, and reproduction in any medium, provided the original author(s) and the source are credited.

\section{References}

Dalal RC, Mayer RJ (1986) Long-term trends in fertility of soils under continuous cultivation and cereal cropping in Southern Queensland. Aust J Soil Res 24:281-292

Darmody RG, Steiner JS, Jansen IJ, Carmer SG (1988) Agricultural impacts of coal mine subsidence: evaluation of three assay methods. J Environ Qual 17:510-513

Darmody RG, Jansen IG, Carmer SG, Steiner JS (1989) Agricultural impacts of coal mine subsidence: effects on corn yields. J Environ Qual 18:265-267

Illinois State Geological Survey (ISGS) (1988) Crops and coal. The Illinois Mine Subsidence Research Program, Illinois State Geological Survey, Champaign

Office of Surface Mining Reclamation and Enforcement (OSMRE) (2011) Report on the effects of longwall mining subsidence mitigation on prime farmland soils for crop production, evaluation year 2011. The Mid-Continent Region, Alton Field Division, Indianapolis Area Office (IAO), OSMRE

Office of Surface Mining Reclamation and Enforcement U.S. Department of the Interior (OSMRE) (2014) http://www.osmre. gob/lrg/chronlisting.shtm. Verified 6 June 2014

Queensland Government (2014) Strategic Cropping Land. http:// www.nrm.qld.gov.au/land/planning/strategic-cropping. Verified 6 June 2014

Tucker RJ, Irvine SA, Godwin MD, McDonald RC (2003) Soils of the Right Bank of the Nogoa River, Emerald Irrigation Area, Queensland. Land Resources Bulletin QNRM03091 